\title{
The production of jaguar paste in Suriname: a product-based crime script
}

\author{
A. M. Lemieux ${ }^{1 *}$ and Nicholas Bruschi ${ }^{2}$
}

\begin{abstract}
As apex predators, jaguars have significant cultural importance in the Americas and are a key species for monitoring the health of ecosystems. Threats to jaguar populations include human-wildlife conflict, habitat destruction, and poaching driven by markets for jaguar products including trophies and traditional Chinese medicine. Using semistructured interviews and participant observations, this short contribution provides a product-based crime script for the production of jaguar paste in Suriname. The findings indicate demand for jaguar paste facilitates opportunistic and organized hunting in and around protected areas, and near extractive industries such as mining and logging. A number of actors, and locations, are involved in the production of paste from live jaguars; the final product is often exported to China after being sold in medicinal shops in Suriname. Possible interventions are included alongside each step in the crime script. The short contribution highlights the potential for using crime scripts in wild life protection to aid prevention efforts.
\end{abstract}

Keywords: Poaching, Jaguar, Suriname, Crime script, Wildlife trade

\section{Introduction}

As apex predators, jaguars have significant cultural importance in the Americas and are a key species for monitoring the health of ecosystems (Cristancho and Vining 2004; Ripple et al. 2014). There are approximately 173,000 jaguars left in the wild, spread across a wide range that connects the southwestern U.S. to Central and South America (Jedrzejewski et al. 2018). The cat has been listed on CITES Appendix I since 1975 and is classified as Near Threatened under the IUCN Red List, with subpopulations outside of Amazonia considered to be the most isolated and threatened (de la Torre et al. 2017). Jaguars face multiple threats, including migration difficulty, human-wildlife conflict and habitat destruction. A particular challenge is the trade in jaguar parts, such as fangs, skulls, claws and skins, which are sold as trophies and traditional Chinese medicine across the Americas and in Asia (Fraser 2018). There are reports that jaguar products are used as a substitute for tiger parts (Bale

\footnotetext{
*Correspondence: alemieux@nscr.nl

${ }^{1}$ Netherlands Institute for the Study of Crime and Law Enforcement (NSCR), Postbus 71304, 1008 BH Amsterdam, The Netherlands

Full list of author information is available at the end of the article
}

2017), but this is just one source of demand. As international demand for jaguar products increases, incentives to hunt these animals illegally do as well. This short contribution presents crime scripts that give insight into the motivation and opportunity structures that facilitate jaguar poaching in Suriname; a country where the killing, possession, transportation, and sale of jaguar products in Suriname is prohibited (Verheij 2019).

\section{Data and methodology}

Crime scripts were developed from semi-structured interviews and participant observations conducted between September 2017 and July 2018 as part of a larger effort to bring attention to jaguar poaching in Suriname through advocacy and research. To capture information on the current supply and demand dynamics of the trade, and the steps involved with processing and selling jaguar products, interviews focused on the prevalence of poaching and trading, the modus operandi of offenders, and consumer profiles. During the first field visit, interviews were conducted with hunters $(n=3)$, local academics leading conservation projects $(n=3)$, law enforcement officials $(n=2)$, and a government representative $(n=1)$. The opportunistic 
sample was identified through an established network built during previous projects in Suriname; interviewees were considered reliable because of prior collaborations and their established roles/expertise. Research assistants also visited curiosity and jewellery shops selling jaguar products, three in Apoera and five in the capital, Paramaribo (see Fig. 1).

During a second field visit, research assistants met with a snowball sample of individuals from the Chinese community in Paramaribo involved with the processing and trading of jaguar products $(n=7)$ for an offender's perspective of the trade. Triangulation of field notes, interviews, and additional information obtained through informal/follow-up conversations was used to develop crime scripts (Cornish 1994). The information was coded so that different stages in the production of jaguar products, i.e. procure/transport/ process/sell, were separated and analysed individually to find commonalities across respondents. A product-based approach (Moreto and Lemieux 2015) was used to develop a script showing the production of a specific product, namely jaguar paste, while an actorbased script was developed for the hunting of jaguars. By following the product, a product-based script highlights the different actors/locations involved rather than the crime process of an individual offender.

\section{Results}

Interviews and field observations suggest there is an emerging market for jaguar 'paste' or 'glue' in Suriname; this has been reported previously but no crime scripts with associated interventions are available (Bale 2018). The respondents indicated demand for this product comes from members of the local Chinese community, as well as a market in mainland China. This is different from the traditional products found in curio shops such as fangs, skulls and skins. The paste is said to be produced by boiling down an entire jaguar carcass in large pans for 5 days, skimming off the top, and letting it simmer for an additional 2 days. This process creates a black, glue-like substance that resembles molasses; it is used for arthritis pain, enhancing general health, and increasing sexual potency. A jaguar is processed into approximately $20-30$ tubs that respondents explained could be placed into the hold luggage of individuals going back to China and sold amongst closed, friend-to-friend networks; the productbased script is presented in Table 1.

The poaching element of the trade is complex. Some animals are killed randomly or opportunistically, for example in self-defence or to protect dogs/cattle/goats, with the knowledge that the carcass can be sold to the Chinese market. Others are killed to fulfil specific commissions for international export; see Table 2. There are reports that in

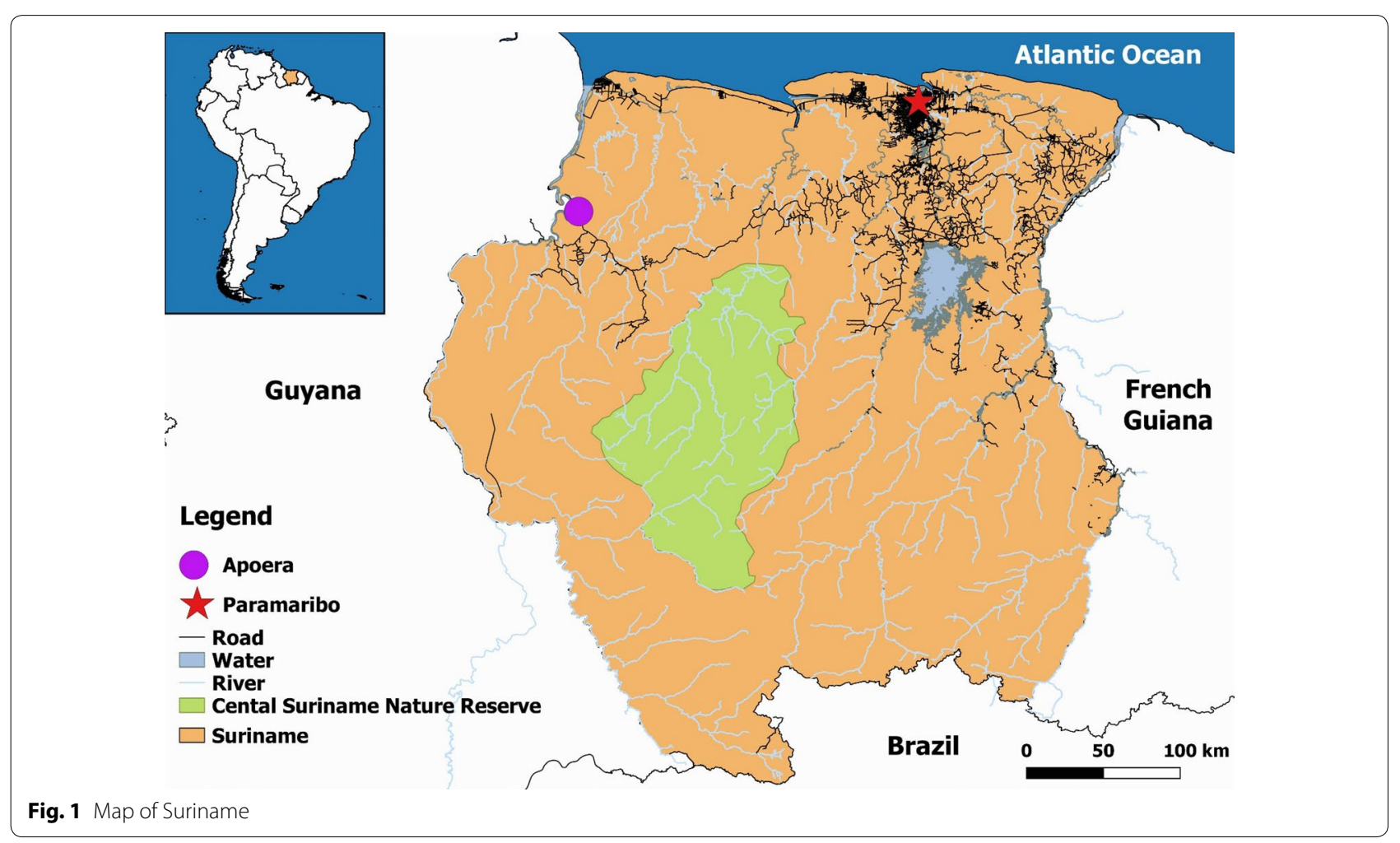


Table 1 Product-based crime script for production of jaguar paste from live animals

\begin{tabular}{|c|c|c|c|c|}
\hline Stages & Steps & Location & Actor(s) & Product status \\
\hline Procure & Find and kill jaguar (see Table 2) & $\begin{array}{l}\text { Wilderness area, community land border- } \\
\text { ing wilderness area, or logging/mining } \\
\text { camp }\end{array}$ & Hunter(s) & Whole carcass \\
\hline Broker & $\begin{array}{l}\text { Contact local Chinese shopkeeper or roving buyer } \\
\text { to sell carcass } \\
\text { Contact person who ordered hunt }\end{array}$ & Community near hunting site & $\begin{array}{l}\text { Hunter } \\
\text { Middleman }\end{array}$ & Whole carcass \\
\hline Broker (2) & Identify paste processor in Paramaribo & Middleman's community (small urban area) & Middleman & Whole carcass \\
\hline Transport & $\begin{array}{l}\text { Move carcass to Paramaribo for processing, pos- } \\
\text { sibly switching cars along the way, using scout } \\
\text { car to avoid law enforcement (late evening/early } \\
\text { morning) }\end{array}$ & Road network & $\begin{array}{l}\text { Middleman } \\
\text { Driver(s) }\end{array}$ & Whole carcass \\
\hline Purchase & Sell carcass to processor & Urban area & $\begin{array}{l}\text { Middleman } \\
\text { Processor }\end{array}$ & Whole carcass \\
\hline Process & $\begin{array}{l}\text { Boil carcass (meat, skin, bones) down into paste } \\
\quad(5-7 \text { days }) \\
\text { Remove teeth and claws for resale }\end{array}$ & Processor home/workshop & $\begin{array}{l}\text { Processor } \\
\text { Shopkeeper }\end{array}$ & $\begin{array}{l}\text { Paste (raw) } \\
\text { Teeth, claws (separate) }\end{array}$ \\
\hline Package & $\begin{array}{l}\text { Put } 500 \mathrm{~g} \text { of paste into individual pots for sale; store } \\
\text { in fridge or freezer }\end{array}$ & Processor home/workshop & Processor & Paste (packaged) \\
\hline Sell & $\begin{array}{l}\text { Sell individual pots to members of the local Chinese } \\
\text { community for use locally or for export }\end{array}$ & $\begin{array}{l}\text { Traditional Chinese Medicine shop } \\
\text { Home of processor }\end{array}$ & $\begin{array}{l}\text { Processor } \\
\text { Exporter } \\
\text { Final Consumer }\end{array}$ & Paste (packaged) \\
\hline Export & Place containers in hand luggage and fly to China & International airport (Suriname) & Exporter & Paste (packaged) \\
\hline Import & Get containers through Chinese customs & International airport (China) & Exporter & Paste (packaged) \\
\hline Resale & Sell individual pots to local networks in China & Unknown & $\begin{array}{l}\text { Exporter } \\
\text { Final Consumer }\end{array}$ & Paste (packaged) \\
\hline
\end{tabular}

Table 2 Crime scripts for hunting live jaguars

\begin{tabular}{|c|c|c|}
\hline Stages & Steps-opportunistic or retaliatory hunt (year-round) & Steps-organized hunt (only in dry season) \\
\hline Preparation & $\begin{array}{l}\text { Organize hunting party following wildlife attack on } \\
\text { humans/livestock/dogs } \\
\text { Organize hunting party to go hunting for species other } \\
\text { than jaguar, such as deer } \\
\text { Obtain weapon and ammunition (privately) } \\
\text { Obtain weapon and ammunition (as part of security role at } \\
\text { a logging/mining concession) }\end{array}$ & $\begin{array}{l}\text { Organize hunting party after order placed by buyer } \\
\text { Obtain weapon and ammunition } \\
\text { Obtain animal to be used as bait }\end{array}$ \\
\hline Entry & Enter forest & Enter forest \\
\hline Pre-condition & $\begin{array}{l}\text { Follow signs of jaguar, or other prey, such as footprints, } \\
\text { droppings, and urine scent }\end{array}$ & Travel to hunting ground \\
\hline Pre-condition & Forage in hunting ground unnoticed & $\begin{array}{l}\text { Tether bait animal } \\
\text { Build hide to shoot from }\end{array}$ \\
\hline Instrumental precondition & $\begin{array}{l}\text { Find jaguar } \\
\text { Randomly encounter jaguar causing fear }\end{array}$ & Jaguar attacks bait animal \\
\hline Instrumental initiation & Prepare weapon and take aim & Prepare weapon and take aim \\
\hline Instrumental actualization & Shoot jaguar & Shoot jaguar \\
\hline Instrumental actualization & Shoot jaguar again if needed & Shoot jaguar again if needed \\
\hline Doing & Let jaguar bleed to death & Let jaguar bleed to death \\
\hline Post-condition & $\begin{array}{l}\text { Build mechanism for transporting jaguar if needed; or carry } \\
\text { over shoulders }\end{array}$ & $\begin{array}{l}\text { Build mechanism for transporting jaguar if needed; or carry } \\
\text { over shoulders }\end{array}$ \\
\hline Exit & $\begin{array}{l}\text { Walk out of forest (back to community or camp); may fol- } \\
\text { low roads or use canoe to reach forest edge }\end{array}$ & $\begin{array}{l}\text { Walk out of forest (back to community or camp); may follow } \\
\text { roads or use canoe to reach forest edge }\end{array}$ \\
\hline Aftermath & Identify broker or roving buyer & Call buyer \\
\hline
\end{tabular}


Table 3 Product-based crime script for production of jaguar paste from live animals with associated responses

\begin{tabular}{|c|c|c|}
\hline Stages & Steps & Potential response $^{a}$ \\
\hline Procure & Find and kill jaguar (see Table 2) & $\begin{array}{l}\text { Increase forest patrols } \\
\text { Mitigate human-wildlife conflict } \\
\text { Embed wildlife ranger in mining/logging camps } \\
\text { Link conservation education to cultural beliefs about jaguars } \\
\text { Stricter controls on weapons possession in reserves and logging/ } \\
\text { mining concessions } \\
\text { Regular checks along logging/mining roads }\end{array}$ \\
\hline Broker & $\begin{array}{l}\text { Contact local Chinese shopkeeper or roving buyer (Chinese/Filipino) } \\
\text { to sell carcass } \\
\text { Contact person who ordered hunt }\end{array}$ & $\begin{array}{l}\text { Encourage natural surveillance by citizens to report carcasses (i.e. see } \\
\text { something, say something) } \\
\text { Encourage natural surveillance by citizens to report roving buyers }\end{array}$ \\
\hline Broker (2) & $\begin{array}{l}\text { Store carcass in small urban } \\
\text { Identify paste processor in Paramaribo }\end{array}$ & $\begin{array}{l}\text { Encourage natural surveillance by citizens to report carcasses (i.e. see } \\
\text { something, say something) }\end{array}$ \\
\hline Transport & $\begin{array}{l}\text { Move carcass to Paramaribo for processing, switching cars along the } \\
\text { way, using scout car to avoid law enforcement (late evening/early } \\
\text { morning) }\end{array}$ & $\begin{array}{l}\text { Regular checks along roads linking forests and known transit settle- } \\
\text { ments to Paramaribo } \\
\text { Combination overt/covert checks to identify cars turning around } \\
\text { before check-points } \\
\text { Build list of suspicious vehicle involved in wildlife product movement }\end{array}$ \\
\hline Purchase & Sell carcass to processor & $\begin{array}{l}\text { Investigations to identify processor identity and workshop locations } \\
\text { (possibly using tracking device on carcass) }\end{array}$ \\
\hline Process & $\begin{array}{l}\text { Boil carcass (meat, skin, bones) down into paste ( } 5-7 \text { days) } \\
\text { Sell teeth and claws to other dealer (may happen earlier) }\end{array}$ & $\begin{array}{l}\text { Encourage residents and landlords to report strange smells that last } \\
\text { several days } \\
\text { Monitor curio shops selling jaguar products }\end{array}$ \\
\hline Package & $\begin{array}{l}\text { Put } 500 \mathrm{~g} \text { of paste into individual pots for sale; store in fridge or } \\
\text { freezer }\end{array}$ & Investigations to identify processors and their workshops ${ }^{b}$ \\
\hline Sell & $\begin{array}{l}\text { Sell individual pots to members of the local Chinese community for } \\
\text { use locally or for export }\end{array}$ & $\begin{array}{l}\text { Monitor WeChat groups for wildlife products }{ }^{b} \\
\text { Regular checking of stores known for selling jaguar products }{ }^{b} \\
\text { Demand-reduction campaign focused on embassy and in-country } \\
\text { professional associations }{ }^{b}\end{array}$ \\
\hline Export & Place containers in hand luggage and fly to China & $\begin{array}{l}\text { Better screening of hold/hand luggage to identify paste (strict } \\
\text { enforcement of liquid/gel rules in hand luggage) } \\
\text { Look for large quantities of jars when screening luggage } \\
\text { Ask questions about tiger balm, wildlife products to identify suspi- } \\
\text { cious persons }\end{array}$ \\
\hline Import & Get containers through Chinese customs & $\begin{array}{l}\text { Increased training to identify jaguar paste in regions known for } \\
\text { importation (i.e. Zhejiang Province) } \\
\text { Build inter-agency network to connect enforcement units in source } \\
\text { and demand countries }\end{array}$ \\
\hline Resale & Sell individual pots to local networks in China & Demand-reduction campaign ${ }^{b}$ \\
\hline
\end{tabular}

a Sustainable funding, combined with regular monitoring and evaluation, is needed for proper implementation given the limited resources currently available

b These responses will require personnel that can read, write and speak Cantonese/Mandarin

these instances a price is generally circulated on the internet (via specific groups for poachers and hunters) or via phone calls from Paramaribo, with buyers willing to pay highly for a "big tiger". This is not said to be very regular but is believed to be increasing. With both types of poaching, income generation is a clear benefit for hunters.

Poaching events were reported to have predominantly occurred near logging operations, mining sites, and close to farming regions. These industries reduce or degrade jaguar habitat, increase access for hunters with new roads, and increase human-jaguar interactions when camps are deep in the forest. Most camps have a shotgun for protection, further increasing opportunities to hunt.

\section{Discussion}

Our findings align with previous work on carnivore poaching in the region showing jaguars are killed as a result of human-wildlife conflict and to supply illegal markets (Paviolo et al. 2008). Moreover, our findings also corroborate the growing literature showing extractive industries, such as logging and mining, create poaching opportunities by bringing humans in contact with wildlife and/or making it easier to access wild areas (Espinosa et al. 2018). As Chinese investment in the region increases (Bernal 2016), in combination with a growing local Chinese population in Suriname (Ellis 2012), the threat to jaguar populations may increase due to greater 
demand for products and more opportunities to access deep forest habitat using new infrastructure.

The findings of this preliminary research have limitations related to the small, opportunistic sample used for interviews. We believe a more systematic approach to crime script production would be beneficial, to increase the reliability and robustness of the scripts presented (Borrion 2013). Further research is needed to confirm if our findings are unique to a specific network of offenders or generalizable across jaguar paste production in Suriname. Questions persist about how the structure/size/ organisation of poachers differ, the number of jaguars taken annually, and the proportion of kills that are opportunistic or to order. Finally, to avoid the Chinese community being stigmatised, respectful outreach is advised to understand the nuances of demand in more depth.

Product-based crime scripts are a unique avenue for future research in wildlife crime. By creating multiple scripts for products originating from the same area, it may be possible to identify patterns in actors, transportation routes and/or consumers. The value of crime scripting lies in the potential for this methodology to identify the dynamic relationships between offenders/places/targets, pinch points and vulnerabilities in the process, and help law enforcement agencies build interagency groups when wildlife products cross jurisdictional boundaries.

Potential interventions based on our current findings are listed in Table 3. These interventions are largely focused on opportunity reduction given a lack of specific information on how offender motivation could be addressed given the variety of actors and locations.

\section{Acknowledgements}

The authors would like to thank William Slattery of World Animal Protection for assisting with fieldwork planning and logistics, and for useful comments on the crime script.

\section{Authors' contributions}

AML was responsible for the writing the main text, including the figures, and helping synthesize field reports into a crime script. NB was responsible for managing the fieldwork, preparing field reports from raw data, and writing the main text. Both authors read and approved the final manuscript.

\section{Funding}

World Animal Protection funded this project.

\section{Availability of data and materials}

The raw data will not be deposited in a publically available repository because it contains personally identifiable information. Requests for data access should be sent to the Nicholas Bruschi.

\section{Competing interests}

The authors declare there are no competing interests.

\section{Author details}

${ }^{1}$ Netherlands Institute for the Study of Crime and Law Enforcement (NSCR), Postbus 71304, 1008 BH Amsterdam, The Netherlands. ${ }^{2}$ World Animal Protection, 5th Floor, 222 Gray's Inn Road, London WC1X 8HB, UK.
Received: 29 March 2019 Accepted: 5 August 2019

Published online: 13 August 2019

\section{References}

Bale, R. (2017). On the trail of jaguar poachers. National Geographic. https:// www.nationalgeographic.com/magazine/2017/12/on-the-trail-of-jagua r-poachers/

Bale, R. (2018). Where jaguars are 'killed to order'for the illegal trade. National Geographic. https://www.nationalgeographic.co.uk/animals/2018/09/ where-jaguars-are-killed-order-illegal-trade

Bernal, R. L. (2016). Chinese foreign direct investment in the Caribbean: Potential and prospects. Inter-American Development Bank. https://publicatio ns.iadb.org/en/publication/12611/chinese-foreign-direct-investment -caribbean-potential-and-prospects

Borrion, H. (2013). Quality assurance in crime scripting. Crime Science, 2(1), 6. https://doi.org/10.1186/2193-7680-2-6.

Cornish, D. B. (1994). The procedural analysis of offending and its relevance for situational prevention. Crime Prevention Studies, 3, 151-196.

Cristancho, S., \& Vining, J. (2004). Culturally defined keystone species. Human Ecology Review, 11,(2) 153-164.

de la Torre, J. A., González-Maya, J. F., Zarza, H., Ceballos, G., \& Medellín, R. A. (2017). The jaguar's spots are darker than they appear: Assessing the global conservation status of the jaguar Panthera onca. Oryx, 52(2), 300-315. https://doi.org/10.1017/s0030605316001046.

Ellis, R. E. (2012). Suriname and the Chinese: Timber, migration, and less-told stories of globalization. SAIS Review, 32(2), 85-97. https://doi.org/10.1353/ sais.2012.0026.

Espinosa, S., Celis, G., \& Branch, L. C. (2018). When roads appear jaguars decline: Increased access to an Amazonian wilderness area reduces potential for jaguar conservation. PLOS ONE, 13(1), e0189740. https://doi.org/10.1371/ journal.pone.0189740.

Fraser, B. (2018). China's lust for jaguar fangs imperils big cats. Nature, 555(7694), 13-14. https://doi.org/10.1038/d41586-018-02314-5.

Jedrzejewski, W., Robinson, H. S., Abarca, M., Zeller, K. A., Velasquez, G., Paemelaere, E. A. D., et al. (2018). Estimating large carnivore populations at global scale based on spatial predictions of density and distributionApplication to the jaguar (Panthera onca). PLoS ONE, 13(3), e0194719. https://doi.org/10.1371/journal.pone.0194719.

Moreto, W. D., \& Lemieux, A. M. (2015). From CRAVED to CAPTURED: Introducing a product-based framework to examine illegal wildlife markets. European Journal on Criminal Policy and Research, 21(3), 303-320. https:// doi.org/10.1007/s10610-014-9268-0.

Paviolo, A., De Angelo, C. D., Di Blanco, Y. E., \& Di Bitetti, M. S. (2008). Jaguar Panthera onca population decline in the Upper Paraná Atlantic Forest of Argentina and Brazil. Oryx, 42(04), 554. https://doi.org/10.1017/s0030 605308000641

Ripple, W. J., Estes, J. A., Beschta, R. L., Wilmers, C. C., Ritchie, E. G., Hebblewhite, M., et al. (2014). Status and ecological effects of the world's largest carnivores. Science, 343(6167), 1241484. https://doi.org/10.1126/scien ce.1241484.

Verheij, P. (2019). An assessment of wildlife poaching and trafficking in Bolivia and Suriname. IUCN NL, Amsterdam. https://www.iucn.nl/files/publi caties/an_assessment_of_wildlife_poaching_and_trafficking_in_boliv ia_and_suriname.pdf

\section{Publisher's Note}

Springer Nature remains neutral with regard to jurisdictional claims in published maps and institutional affiliations. 